\title{
TRANSLOCATION OF THE BONTEBOK \\ (Damaliscus Pygargus)' \\ FROM BREDASDORP TO SWELLENDAM
}

\author{
By P. J. BARNARD \\ (Biologist Cape Parks) and \\ Dr. K. VAN DER WALT \\ (Division of Veterinary Services)
}

The Bontebok National Park which was proclaimed in 1931, was situated in the Bredasdorp district not very far from Cape Agulhas, the southernmost tip of Africa. The vegetation of the area is described by Acocks as Coastal Macchia, which, as far as the bontebok are concerned, is not the ideal habitat, since the grazing is of a mediocre quality and very little natural shelter exists. It has been suggested that the bontebok did not choose to roam this area of a free will, insiead, they were forced to retreat before the settlers who cultivated the best grazing areas.

At the time of its proclamation, the Park, 843 morgen in extent, supported 17 bontebok. These increased at a reasonable rate until the herd approached the one hundred mark. It then became evident that the Park was not large enough to support a greater number. The Board therefore decided to thin out the herd every year by organizing drives to capture a number of animals and distribute them among the local farmers. This effort to stimulate the increase of bontebok was not wholly successful, consequenily the Board abandoned the scheme and endeavoured, insiead, to improve the carrying capacity of the grazing in the Park by establishing artificial pastures but this also proved not to be the solution, for every year a considerable number of boniebok, especially young animals, died and the herd never numbered many more than one hundred.

In March 1957, dr. T. Smuts, a private veterinarian visited the Park to perform a post-mortem on a bontebok. He reported that the animal suffered from severe verminosis. Conical fluke (Paramphistomum sp.), Wireworm (Haemonchus sp.), Brown stomachworm (Ostertagia) and Bankruptworm (Tri. chostrongylus sp.) were found in great numbers.

He also drew attention to weakness and signs of ataxia in several animals in spite of them appearing to be in reasonable condition. A diagnosis of "swayback" (a copper deficiency) was made. This opinion was supported by the wellknown fact that the South-Western coastal belt is deficient in copper, and that severe worm infestation aggravates the condition.

1. Roberts, A. (1951). The Mammals of South Africa, Cape Times, Cape Town. 
A concerted effort was subsequently made by the Board to acquire more land in order to introduce a system of alternative grazing. However, none of the neighbouring farmers could be induced to sell any land and a stalemate iherefore resulted. The only alternative was to procure a suitable area elsewhere and to transfer the bontebok.

After a very long search a suitable tract of land was found near the town of Swellendam, approximately 60 miles distant from the old Park. It was bought by the Department of Lands and after being properly fenced in by the Board the bontebok could be transferred.

\section{METHOD AND PROCEDURE.}

Preliminary experiments were conducted with the addition of Chloral hydrate and Sodium phenobarbitone to the drinking water to capture the bontebok in this manner. However, it did not prove successful because:

i. Approximately one half of the herd never seemed to be in need of water.

ii. Those animals that did come to drink, drank so little that the concentration of the drug would have had to be so high in order to be effective, that it would have rendered the water unpalatable.

iii. All the animals drank very irregularly and in cool weather failed to drink at all.

iv. Since lactating ewes drank more than the other animals it would have been impossible to prepare an effective yet safe concentration.

The only method which remained was to capture the animals in crushpens. Three of these were erected, each having a funnel-shaped camp ranging from a half to one and a half morgen in extent. These camps were strengthened by jackal-proof wire netting and ended in a crush-pen which measured 18 inches in width, 10 yards in length and four feet high. The narrowness of the crush-pen ensured that no bontebok, once in, could turn around or squeeze in next to another animal, thereby increasing the danger of injury. The end of the crush-pen was closed off with a collapsible gate.

A group, consisting of 25 bontebok were trapped in one of the small camps when they came to drink, but the rest of the 84 animals which were eventually captured had to be driven in, in groups ranging from eight to twelve. A number of motor vehicles were used to drive the animals into the small camps, from where it proved very simple to drive them into the crushpens. As soon as this was accomplished a number of natives who lay hidden close to the crush-pen quickly came forward, opened the gate and pulled the bontebok from the crush by their horns. Thereupon each animal was held down by a number of natives in order that the tranquilizer could be administered. The first 18 animals were thereafter dosed with phenothiazine.*

\footnotetext{
- Performed by Dr. R. J. Ortlepp, Helminthologist, Onderstepoort.
} 
This was done with the cid of a rubber extension tube on a dosing syringe. Two of the animals in the first batch died on the way to the new Park and after it was established at post-mortem that they were grossly infested with conical fluke (Paramphistomum microbothrium) and lungworm (Protostrongylus (S.L.) spp.) both being insusceptible to phenothiazine and only very lightly with wireworm (Haemonchus contortus), bankruptworm (Trichostrongylus spp.) and Nematodirus spathiger, dosing was discontinued.

\section{SEDATION.}

Immediately after securing the animals each one was injected intravenously with a $5 \%$ solution of ch!orpromazine hydrochloride ("Largactil"). The weights varied considerably because some animals were in extremely poor condition, but the mean weight was estimated at approximately $70 \mathrm{lbs}$. for ewes and up to $120 \mathrm{lbs}$. for fullgrown rams in good condition. Lambs and halfgrown animals were not treated, mainly because they were not regarded as being a danger to themselves or other animals during transportation.

Various dosage levels were tried but it was soon evident that an intravenous dose of $150 \mathrm{mg}$. $13 \mathrm{cc}$.) for a fullgrown ram had the desired effect. The dosage rate was scaled down for lighter animals.

The animals relaxed completely within about four minutes after the injection and ceased struggling. Within approximately ten minutes they were observed to go down, lying on their sternums with their noses on the ground and the heads often lying sideways. Some animals were inclined to roll over on their sides and in these cases all efforts were made to keep them in a sternal position to prevent bloat and choking from their own saliva. Profuse salivation was observed in the more heavily sedated animals, probably due to a suppression of the swallowing reflex, byt no difficulty was encountered with bloat, provided the animals were not allowed to remain on their sides.

The effect and duration of sedation varied, but can be described in three groups. The first group were able to stay on their feet with some difficulty but did not appear apprehensive. When let loose they were able to run away without difficulty and appeared normal. The second group was inclined to lie down for four to six hours if left undisturbed. When roused they were able to run away shakily. Some were observed to lie down after a few hundred yards while others regained normality quickly. The third group consisted mainly of old thin animals of which some were pregnant ewes. These animals became comatose soon after the injection and were inclined to go over on their sides. They could not be roused and stayed down for up to 24 hours.

\section{TRANSPORTATION.}

Two vehicles were used for transporting the bontebok, the one an old school bus from which the seats were removed and all the windows covered, 
and the other an ordinary covered three ton truck. As soon as the animals had relaxed completely, they were loaded into one of the vehicles and bedded down in a sternal position on a thick layer of straw. It was found that the maximum number of animals that could comfortably be taken at a time was eighteen. Two attendanis accompanied the animals every time in order to see to it that they remained in an upright position and to prevent one animal possibly injuring another. Those animals still capable of standing lay down shorily after the vahicle came in:o motion.

The journey took about two to two and a half hours and the bontebok were unloaded and released immediately upon arrival in the new Park. The ones which could not be roused were left unmolested in the open.

RESULTS.

Of the 95 bontebok in the old Park, 84 were captured, whilst the remaining eleven were leitt for the Department of Nature Conservation of the Cape Province, whose officials captured these animals three days later.

A single ewe had to be destroyed on account of a fractured femur. This happened when the animal escaped past two natives out of the crush-pen and ran headlong inio a fence. She was capiured subsequently in the ve'd.

Sixty one of the 84 boniebok that were transferred survived the critical first three days in the new Park. A detailed analysis of the cause of death of the twenty three animals is not possible as there were several contributory factors.

Altogether eight bontebok died during the transportation. Subsequent post-mortems revealed that without exception these animals showed severe lungworm infestation, but the outstanding symptom was gross endocardial haemorrhages which was ascribed to over-exhaustion. The lesions appeared to be so severe that the animals could not have survived.

A few of the bontebok were unloaded in a comatose condition and could noi be roused. They died within the next twenty four hours and it must be assumed that the main cause was over-sedation. They were, however, without exception animals in poor condition and some were heavily pregnant. Auscultation in some of these cases revealed marked conduciion disturbances in the heart, which were probably caused by endocardial haemorrhages.

Four bontebok were found dead at the water's edge of the river on the second day and on the same day, and also on the third day, a number of animals were found dead in the veld. It is possible that the four animals died of over-indulgence of waier, but it seems more likely that they, and the others found in the veld, died presumably of prussic acid poisoning, since at the time there was hardly any green plant material in the old Park whilst in the new Park most of the plants showed new growth.

Only two more bontebok died during the rest of the year, both being 
very old animats, but ten lambs were dropped, so that the herd now numbers 69. The heavy losses which occurred in the old Park regularly towards the end of the winter was someihing unknown this year with the bontebok in the finest condition in which they have ever been known to be.

\section{CONCLUSION.}

1. The whole operation was remarkably successful, when it is considered that only one animal was fatally injured in the process of capture.

2. The loss of 23 anima!s out of a herd of 84 during trans!ocation, is slight when it is borne in mind that no selection took place, all animals, including the very old and thin animals were captured.

3. On the whole, sedation by means of intravenous administration of chlorpromazine hydrochloride was remarkably effective, despite the fact that the dosage rate had to be determined on an empirical basis, since no previous information was available.

4. The cool, overcast weather conditions were extremely favourable for the capture, and contributed greatly towards the success achieved. 